\title{
Variasi jumlah dan panjang batang pengupas pada mesin pengupas buah pinang terhadap efisiensi pengupasan buah pinang kering
}

\author{
Iman Syahrizal1${ }^{*}$, Daud Perdana ${ }^{2}$ \\ 1,2,Jurusan Teknik Mesin, Politeknik Negeri Sambas \\ JI. Raya Sejangkung, Sambas, Kalimanatan Barat, Indonesia \\ ${ }^{*}$ Corresponding author : imansyahrizal22@gmail.com
}

\begin{abstract}
The process of peeling betel nuts can be done manually or using a machine. Peeling betel nuts using a machine is easier and faster than peeling them manually. This study aimed to test the performance of the dry betel nut peeler machine and to prove the effect of the number and length of peeling rods on the efficiency of the peeling. The method used in this study was a randomized design experimental method consisting of two factors, namely the number of peeling rods (12 rods; 18 rods; 24 rods) and the length of the peeling rods $(1 \mathrm{~cm} ; 1.5 \mathrm{~cm} ; 2$ $\mathrm{cm}$ ) with nine test variations. . The parameters observed included percentage of unpeeled fruit, percentage of peeled fruit with broken seeds, and percentage of peeled fruit with unbroken seeds. The highest peeling efficiency was $88 \%$ at the interaction of the number of peeling rods of 18 pieces $1,5 \mathrm{~cm}$ long. The lowest stripping efficiency was $66 \%$ at the interaction of the number of peeling rods of 12, $2 \mathrm{~cm}$ long and the average stripping efficiency was $76 \%$. The greater the number of peeling rods, the greater the percentage of peeled fruit. The longer the peeler rod, the greater the percentage of peeled fruit with broken seeds.
\end{abstract}

Keywords: dry betel nut, peeler, efficiency.

\begin{abstract}
Abstrak
Proses pengupasan buah pinang dapat dilakukan dengan cara manual ataupun dengan menggunakan mesin. Pengupasan buah pinang dengan menggunakan mesin tergolong lebih mudah dan lebih cepat dibandingkan pengupasan secara manual. Penelitian ini bertujuan untuk melakukan uji kinerja mesin pengupas buah pinang kering dan membuktikan pengaruh jumlah batang pengupas dan panjang batang pengupas terhadap efisiensi pengupasan. Metode yang digunakan dalam penelitian ini adalah metode eksperimen rancangan acak yang terdiri dari dua faktor yaitu jumlah batang pengupas (12 batang ; 18 batang ; 24 batang) dan panjang batang pengupas $(1 \mathrm{~cm} ; 1,5 \mathrm{~cm} ; 2 \mathrm{~cm})$ dengan sembilan variasi pengujian. Parameter yang diamati meliputi persentase buah tidak terkupas, persetase buah terkupas dengan biji pecah, dan persentase buah terkupas dengan biji tidak pecah. Efisiensi pengupasan tertinggi adalah 88\% pada interaksi jumlah batang pengupas 18 buah panjang $1,5 \mathrm{~cm}$. Efisiensi pengupasan terendah adalah $66 \%$ pada interaksi jumlah batang pengupas 12 buah panjang $2 \mathrm{~cm}$ dan efisiensi pengupasan rata-rata adalah sebesar $76 \%$. Semakin banyak jumlah batang pengupas maka persentase buah terkupas semakin besar. Semakin panjang batang pengupas maka pesentase buah terkupas dengan biji pecah semakin besar.
\end{abstract}

Kata kunci: Pinang kering, batang pengupas, efisiensi.

\section{Pendahuluan}

Pinang pada dasarnya merupakan tanaman yang sering digunakan oleh mayarakat, khususnya masyarakat pedalaman yang memiliki kebiasaan mengunyah biji pinang bersama-sama dengan daun sirih dan kapur [1]. Selain itu pinang juga merupakan tanaman yang memiliki banyak manfaat terutama bijinya. Biji pinang banyak dimanfaatkan sebagai 
bahan baku utama pembuatan obat, kosmetik, pelangsing, makanan ringan dan permen [2].

Budidaya pinang mulai dilirik sejumlah petani Indonesia khususnya di Aceh, Jambi, Riau, Sumatera Barat, Bengkulu, Jawa Barat, Jawa Tengah, Jawa Timur, Kalimantan Barat, Kalimantan Selatan, Nusa Tenggara Barat dan Papua. Pinang merupakan komoditas tanaman yang di ekspor ke berbagai negara seperti Pakistan, Thailand, India, singapura dan Myanmar. Pinang yang menjadi komoditas ekspor adalah pinang yang sudah berbentuk biji atau yang sudah terkupas sabut dari batoknya [3]. Penanganan pasca panen buah pinang untuk mendapatkan bijinya memerlukan proses yang cukup lama. Proses ini kebanyakan dilakukan pada buah yang sudah masak, namun ada juga yang dilakukan pada buah yang masih muda, tergantung dari keperluannya.

Proses pengupasan buah pinang dapat dilakukan dengan cara manual ataupun dengan menggunakan mesin. Pengupasan dengan cara manual biasanya dilakukan dengan membelah buah pinang menjadi dua menggunakan parang atau alat sejenisnya, setelah itu buah pinang yang sudah dibelah dikeringkan dengan cara dijemur, pengupasan dengan cara ini tentu memerlukan waktu yang cukup lama dan sangat beresiko terhadap kecelakaan kerja [3]. Pengupasan buah pinang dengan cara manual menggunakan parang atau pisau hanya mampu menghasilkan 10-15 kg/hari [4]. Pengupasan buah pinang dengan menggunakan mesin tergolong lebih mudah dan lebih cepat dibandingkan pengupasan secara manual, buah pinang yang sudah dipanen bisa langsung dimasukkan ke hooper pengupasan, sehingga hasil pengupasan menggunakan mesin dapat menghemat waktu dan juga tenaga serta dapat meningkatkan produksi dari biji pinang [3]. Mesin pengupas kulit pinang adalah mesin yang digunakan untuk mengupas kulit luar pinang sehingga menghasilkan biji pinang dengan cepat [5].
Dari analisa mesin pembelah pinang didapatkan hasil bahwa mesin mampu membelah buah pinang sebanyak 120 $\mathrm{kg} / \mathrm{jam}$, dimana $75 \%$ hasilnya terbelah dengan sempuna [6].

\section{Tinjauan Pustaka}

Pinang merupakan tanaman monokotil dan termasuk famili Palmaceae, genus Areca. Pinang juga merupakan tanaman berumah satu (monoceous), yang mana bunga betina dan bunga jantan berada dalam satu tandan dan menyerbuk silang. Buah pinang termasuk buah drupe (buah batu) karena lapisan bagian dalamnya atau endocarp liat, tebal dan keras seperti batu, berwarna kuning sampai oranye pada saat masak. Pericarp bersabut dengan ketebalan 5-6 mm. Biji berbentuk lonjong, bulat, atau elip, dengan bagian dasar biji rata[7].

Panen dapat dilakukan dengan dua cara sesuai dengan kebutuhan produk pinang yang diinginkan, yaitu panen buah masak penuh dan panen buah muda. Tanda buah siap panen adalah warna kulit berwarna kuning kehijauan atau oranye.

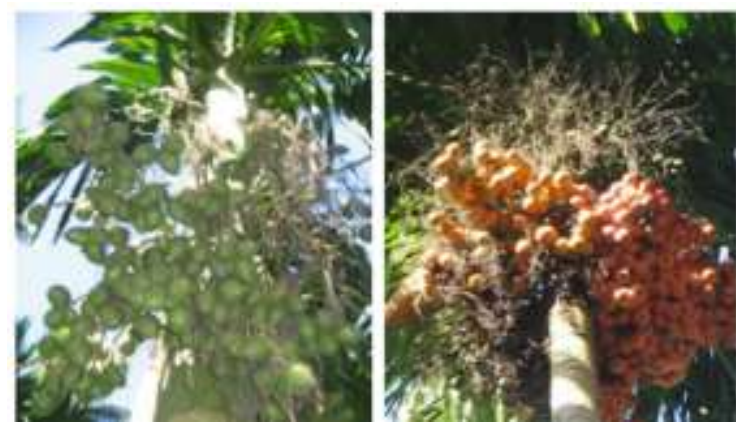

Gambar 1. Buah pinang muda dan buah pinang masak (sumber [7])

Panen buah muda biasanya dilakukan sesuai dengan kebiasaan konsumsi buah pinang, seperti di Papua yang memanen buah muda kira-kira berumur 3-4 bulan. Biasanya buah dengan umur demikian kernel (endosperm) masih lembut [7].

Buah pinang yang sudah dipanen kemudian dibelah menjadi dua dan dikeringkan dengan panas sinar matahari, setelah kering buah dicungkil dan dijemur kembali selama 50 jam. Penjemuran berlangsung selama 4 hari secara berturut- 
turut. Setelah kering biji pinang dapat dikemas dalam karung plastik untuk dijual atau disimpan dalam gudang.

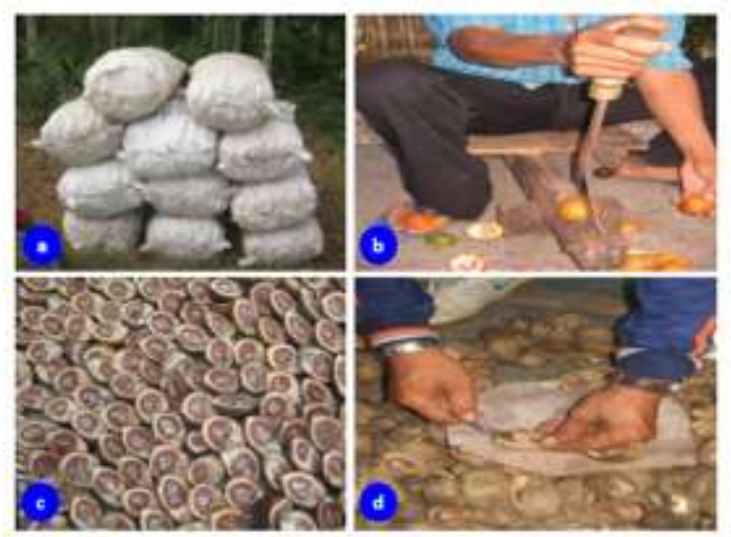

Gambar 2. Penanganan buah pinan pasca panen (sumber [7])

Biji pinang yang diekspor sebagian besar $(66,20 \%)$ termasuk mutu II dan hanya sebagian kecil $(23,80 \%)$ yang termasuk mutu I. Oleh karena itu, diperlukan perbaikan teknologi pengolahan buah pinang, mulai dari tingkat petani, pedagang pengumpul hingga tingkat eksportir, agar mutu biji pinang meningkat dan harganya lebih tinggi. Pengolahan harus menggunakan teknologi yang lebih baik dan secara mekanis [8].

Penelitian mengenai mesin pengupas sabut pinang telah banyak dilakukan, diantaranya telah diteliti variasi kecepatan putar screw feeding dengan kecepatan putar pisau pengupas terhadap kualitas hasil pengupasan pada mesin pengupas kulit pinang secara eksperimental. Hasil penelitiannya menunjukkan bahwa variasi kecepatan putaran antara screw feeding dan pisau pengupas untuk pengupasan yang optimal didapat pada kecepatan putaran 37 rpm pada screw feeding dan $800 \mathrm{rpm}$ pada pisau pengupasan, sedangkan kecepatan 27 rpm pada screw feeding dan 560 pada pisau pengupas tidak bisa mengupas buah pinang karena buah pinang terjepit di antara keduanya [9].

Penelitian lainnya merancang bangun mesin pengupas buah pinang. Mesin ini digunakan untuk mengupas buah pinang dengan metode penghempasan. Pinsip kerja mesin ini adalah buah pinang yang masuk melalui hopper akan langsung ditampung oleh concave slave, disini buah akan dihempas oleh karet pengupas. Karet yang telah dipasang pada dudukan ini akan berputar di dalam cangkang yang akan menghempas buah pinang. Proses ini akan terus berulang-ulang sampai biji buah benarbenar lepas dari kulitnya. Biji yang telah terkupas nantinya akan meluncur masuk menembus concave slave, begitu juga dengan kulitnya, sedangkan untuk buah yang belum terkupas akan terus dilakukan proses pengupasan [10].

\section{Metode Penelitian}

Metode yang digunakan dalam penelitian ini adalah metode eksperimen rancangan acak yang terdiri dari dua faktor yaitu jumlah batang pengupas (12 batang; 18 batang ; 24 batang) dan panjang batang pengupas $(1 \mathrm{~cm} ; 1,5 \mathrm{~cm} ; 2 \mathrm{~cm})$ dengan sembilan variasi pengujian, di antaranya :

1. Pengujian 12 batang pengupas dengan panjang $1 \mathrm{~cm}$.

2. Pengujian 12 batang pengupas dengan panjang $1,5 \mathrm{~cm}$.

3. Pengujian 12 batang pengupas dengan panjang $2 \mathrm{~cm}$.

4. Pengujian 18 batang pengupas dengan panjang $1 \mathrm{~cm}$.

5. Pengujian 18 batang pengupas dengan panjang $1,5 \mathrm{~cm}$.

6. Pengujian 18 batang pengupas dengan panjang $2 \mathrm{~cm}$.

7. Pengujian 24 batang pengupas dengan panjang $1 \mathrm{~cm}$.

8. Pengujian 24 batang pengupas dengan panjang $1,5 \mathrm{~cm}$.

9. Pengujian 24 batang pengupas dengan panjang $2 \mathrm{~cm}$.

Parameter yang diamati meliputi persentase buah tidak terkupas, persetase buah terkupas dengan biji pecah, dan persentase buah terkupas dengan biji tidak pecah.

Tahapan penelitian disusun dalam bentuk diagram alir seperti pada gambar 3 . 


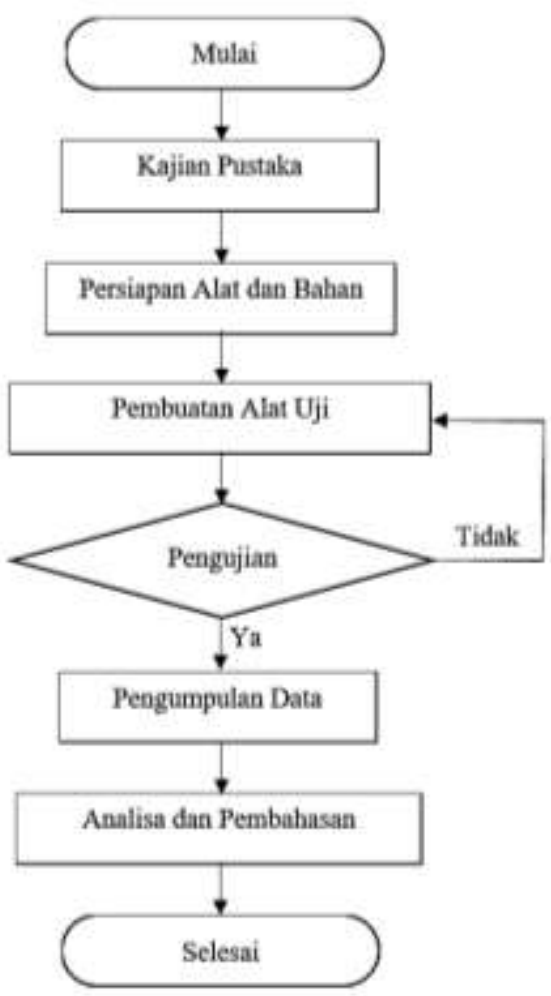

Gambar 3. Diagram alir penelitian

Tahapan proses pengujian yang dilakukan adalah sebagai berikut:

1. Menyiapkan mesin (alat uji) dan alat pendukung lainnya.

2. Menyiapkan alat ukur (mistar baja untuk panjang batang pengupas dan tachometer untuk mengukur putaran rotor pengupas).

3. Menyiapkan bahan uji (buah pinang) yang sudah dikeringkan dengan cara dijemur masing-masing 50 buah pinang untuk satu kali pengujian.

4. Mengatur jumlah dan menyetel panjang batang pengupas yang dibuat dari baut ukuran $14 \mathrm{~mm}$ sesuai dengan urutan variasi pengujian yang telah ditentukan.

5. Menutup dan mengunci ruang pengupasan dengan menggunakan baut pengunci.

6. Menghidupkan mesin.

7. Menentukan putaran rotor pada 1400 rpm dengan cara mengatur handel putaran motor penggerak.

8. Menyimpan bak dibawah saluran keluaran untuk menampung buah yang akan keluar.
9. Memasukkan bahan uji (buah pinang kering) kedalam ruang pengupasan melalui corong saluran masuk secara perlahan sesuai dengan jumlah yang telah ditentukan.

10. Proses pengupasan buah berlangsung di ruang pengupasan dan buah yang hasilnya akan langsung keluar melalui saluran keluaran.

11. Mematikan mesin dan melakukan pemilahan hasil pengujian.

12. Mengulangi tahapan yang sama sampai 3 kali pengulangan untuk mendapatkan data yang baik.

13. Menglangi kegiatan nomor 6 s/d 12 sampai proses pengujian selesai.

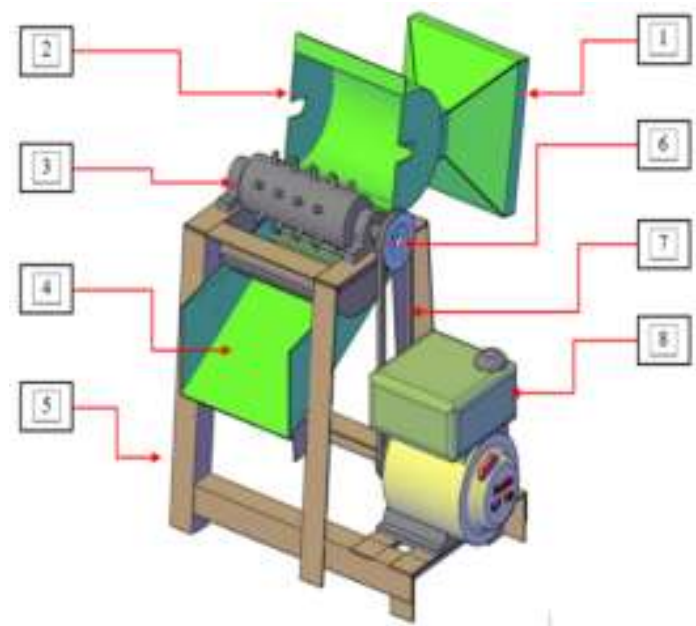

Gambar 4. Desain konstruksi mesin pengupas pinang kering

Tabel 1. Keterangan Gambar 4

\begin{tabular}{cc}
\hline No Komponen & Nama Komponen \\
\hline 1 & Corong masuk \\
\hline 2 & Tutup rotor pengupas \\
\hline 3 & Rotor pengupas \\
\hline 4 & Saluran keluaran \\
\hline 5 & Rangka mesin \\
\hline 6 & Pully \\
\hline 7 & V belt \\
\hline 8 & Motor penggerak
\end{tabular}
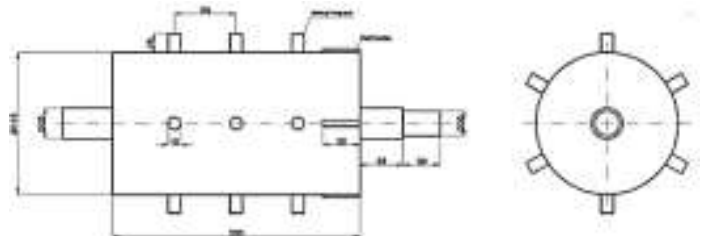

Gambar 5. Desain Konstruksi rotor batang pengupas 


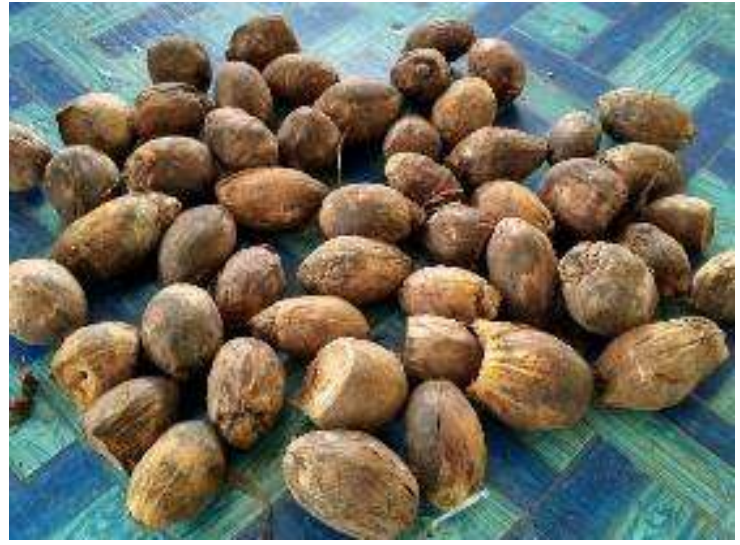

Gambar 6. Buag pinang kering

\section{Hasil dan Pembahasan}

Hasil uji kinerja mesin pengupas buah pinang kering yang dilakukan dengan 9 variasi pengujian tampilkan dalam Tabel 2.

Tabel 2. Rata-rata Efisiensi Pengupasan Buah Pinang Kering

\begin{tabular}{|c|c|c|c|c|c|c|}
\hline 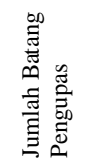 & 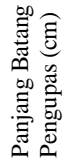 & 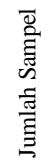 & 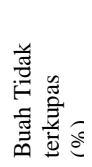 & 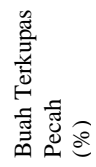 & 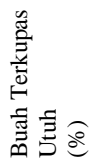 & 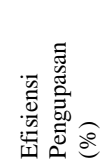 \\
\hline 12 & 1 & 50 & 14 & 16 & 70 & 70 \\
\hline 12 & 1.5 & 50 & 8 & 18 & 74 & 74 \\
\hline 12 & 2 & 50 & 6 & 28 & 66 & 66 \\
\hline 18 & 1 & 50 & 2 & 14 & 84 & 84 \\
\hline 18 & 1.5 & 50 & 0 & 12 & 88 & 88 \\
\hline 18 & 2 & 50 & 0 & 22 & 78 & 78 \\
\hline 24 & 1 & 50 & 0 & 18 & 82 & 82 \\
\hline 24 & 1.5 & 50 & 0 & 22 & 78 & 78 \\
\hline 24 & 2 & 50 & 0 & 32 & 68 & 68 \\
\hline \multicolumn{5}{|c|}{ Efisiensi Pengupasan Maximum } & \multicolumn{2}{|c|}{88} \\
\hline \multicolumn{5}{|c|}{ Efisiensi Pengupasan Minimum } & \multicolumn{2}{|c|}{66} \\
\hline \multicolumn{5}{|c|}{ Efisiensi Pengupasan Rata-rata } & \multicolumn{2}{|c|}{76} \\
\hline
\end{tabular}

Tabel 2 memperlihatkan bahwa efisiensi pengupasan tertinggi adalah $88 \%$ pada interaksi jumlah batang pengupas 18 buah panjang $1.5 \mathrm{~cm}$. Efisiensi pengupasan terendah adalah $66 \%$ pada interaksi jumlah batang pengupas 12 buah panjang $2 \mathrm{~cm}$ dan efisiensi pengupasan rata-rata adalah sebesar $76 \%$.

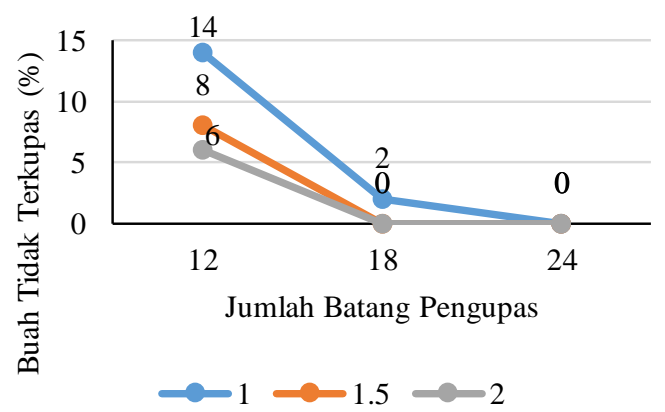

Gambar 7. Grafik persentasi rata-rata buah tidak terkupas

Buah pinang yang tidak terkupas paling banyak pada interaksi jumlah batang pengupas 12 buah panjang $1 \mathrm{~cm}$ yaitu $14 \%$. Pada interaksi jumlah batang pengupas 12 buah panjang $1.5 \mathrm{~cm}$, pinang yang tidak terkupas sebesar $8 \%$, dan pada interaksi jumlah batang pengupas 12 buah panjang 2 $\mathrm{cm}$, pinang yang tidak terkupas sebesar $6 \%$. Pengujian dengan interaksi jumlah batang pegupas 18 buah panjang $1 \mathrm{~cm}$, pinang yang tidak terkupas sebanyak 2\%. Pengujian dengan interaksi jumlah batang pegupas 18 buah panjang $1.5 \mathrm{~cm}$, pinang yang tidak terkupas $0 \%$. Pengujian dengan interaksi jumlah batang pegupas 18 buah panjang 2 $\mathrm{cm}$, pinang yang tidak terkupas $0 \%$. Pengujian dengan interaksi jumlah batang pengupas 24 buah panjang $1 \mathrm{~cm}, 1.5 \mathrm{~cm}$, dan $2 \mathrm{~cm}$ pinang yang tidak terkupas juga $0 \%$. Ini memberikan informasi bahwa semakin banyak jumlah batang pengupas maka persentase pinang yang tidak terkupas semakin kecil bahkan sampai pada angka $0 \%$ yang artinya semua buah pinang kering dapat terkupas.

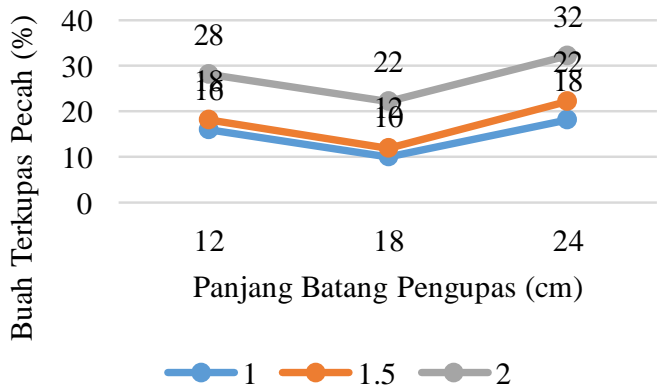

Gambar 8. Grafik persentase rata-rata buah terkupas dengan biji pecah

Buah pinang yang terkupas dengan biji pecah paling banyak terjadi pada 
interaksi panjang batang pengupas $2 \mathrm{~cm}$, keuadian panjang $1.5 \mathrm{~cm}$ dan yang paling sedikit adalah pada panjang $1 \mathrm{~cm}$. Buah pinang yang terkupas dengan kondisi biji pecah terbanyak adalah pada interaksi jumlah batang pengupas 24 buah panjang 2 $\mathrm{cm}$ yaitu $32 \%$. Buah pinang yang terkupas dengan kondisi biji pecah paling sedikit adalah pada interaksi jumlah batang pengupas 18 buah panjang $1.5 \mathrm{~cm}$ yaitu $10 \%$.

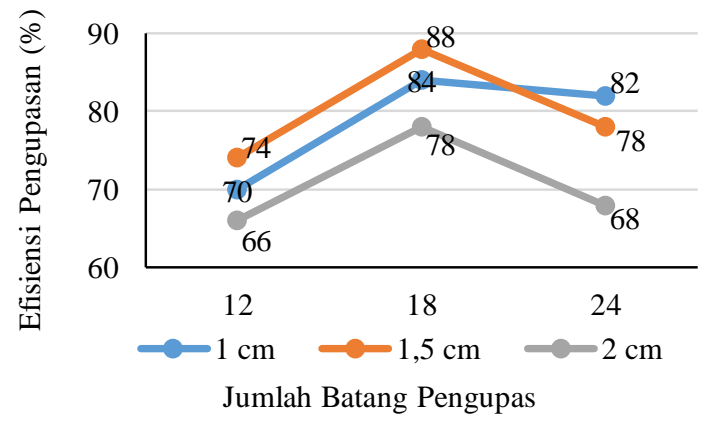

Gambar 9. Grafik efisiensi pengupasan buah pinang kering

Efisiensi pengupasan buah pinang terbaik dari uji kinerja mesin pengupas adalah pada rotor dengan jumlah batang pengupas 18 buah panjang 1,5 cm dengan tingkat efisiensi $88 \%$. Pada interaksi ini pengujian 50 buah pinang kering yang dimasukkan ke dalam mesin pengupas dapat terkupas semuanya dengan hasil 6 buah pinang terkupas dengan biji pecah dan 44 buah pinang terkupas dengan biji utuh. Pada uji kinerja rotor dengan jumlah batang pengupas 12 buah, efisiensi tertinggi adalah pada interaksi panjang batang pengupas $1,5 \mathrm{~cm}$ yaitu $74 \%$. Pada interaksi ini pengujian 50 buah pinang kering terdapat 7 buah tidak terkupas, 8 buah terkupas dengan biji pecah dan 35 buah terkupas dengan biji utuh. Sedangkan pada uji kinerja rotor dengan jumlah batang pengupas 24 buah, efisiensi tertinggi terjadi pada interaksi panjang batang pengupas $1 \mathrm{~cm}$ yaitu $82 \%$. Pada interaksi ini pengujian 50 buah pinang kering terkupas semuanya dengan hasil 9 buah pinang terkupas dengan biji pecah dan 41 buah pinang terkupas dengan biji utuh.
Dari hasil pengamatan visual buah pinang yang terkupas dengan biji pecah adalah buah pinang yang sudah terlalu tua sehingga tekstur bijinya sudah rapuh. Hal ini sama dengan peryataan yang disampaikan pada penelitian sebelumnya [9]. Selain itu juga disebabkan oleh kualitas buah pinang yang tidak baik [4]. Batang pengupas yang telalu panjang juga menjadi penyebab terjadinya benturan yang terlalu keras antara batang pengupas dengan buah saat rotor berputar. Buah pinang terkupas pecah juga disebabkan pinang yang jatuh setelah berbenturan dengan casing bisa saja kembali mengenai mata pisau karena tidak ada pembatas antara screw feeding dan mata pisau [9].

\section{Kesimpulan}

Efisiensi pengupasan tertinggi adalah $88 \%$ pada interaksi jumlah batang pengupas 18 buah panjang $1,5 \mathrm{~cm}$. Efisiensi pengupasan terendah adalah $66 \%$ pada interaksi jumlah batang pengupas 12 buah panjang $2 \mathrm{~cm}$ dan efisiensi pengupasan rata-rata adalah sebesar $76 \%$. Semakin banyak jumlah batang pengupas maka persentase buah terkupas semakin besar. Semakin panjang batang pengupas maka pesentase buah terkupas dengan biji pecah semakin besar.

\section{Referensi}

[1] T. Satriadi, "Kadar tanin biji pinang (Areca catechu L.) dari pleihari," J. Hutan Trop., vol. 12, no. 32, pp. 132135, 2011.

[2] R. Barlina, "Peluang Pemanfaatan Buah Pinang Untuk Pangan Opportunity of Arecanut for Food Utilizing," Bul. Palma, vol. 33, pp. 96-105, 2007.

[3] A. Pranata, Yohanens, and Satriardi, "Perancangan Mesin Pengupas Buah Pinang Berbasis Metode Quality Function Deployment (Qfd)," JOM FTEKNIK, vol. 3, pp. 1-5, 2016. 
[4] S. Deny Alfian, Darmein, "Membuat Mesin Pengupas Kulit Buah Pinang Kering," J. Mesin Sains Terap., vol. 2, no. 1, pp. 34-38, 2018.

[5] I. P. Erizal, Y. Yetri, Nusyirwan. " Perancangan Perawatan Mesin",JURNAL Teknik Mesin, vol. 11, no. 1, pp. 11-15, 2018.

[6] Sukadi, A. Kurniawan. "Raancang Bangun Mesin Pembelah Pinang", TEKNIKA : Jurnal Teknik, vol. 7, no. 2, pp. 168-174, 2020.

[7] Miftahorrachman, Y. R. Matana, and Salim, "Teknologi Budidaya dan Pasca Panen Pinang," Balai Penelitian Tanaman Palma, Manado, 2015.

[8] H. Novarianto, "Prospek Pengembangan Tanaman Pinang", Jurnal Warta Penelitian dan Pengembangan Pertanian Indonesia, vol. 34, no. 1, pp. 10-11, 2012.

[9] I. K. Hasanul Hakim, Yohanes, "Eksperimental Variasi Kecepatan Putar Feeding Dengan Kecepatan Putar pisau Pengupas Terhadap Kualitas Hasil Pengupasan Kulit Pinang," vol. 3, no. 1, pp. 1-5, 2016.

[10] F. R. Ade Hendra, "METAL : Jurnal Sistem Mekanik dan Termal Rancang Bangun Mesin Pengupas Buah Pinang," J. Sist. Mek. Dan Termal, vol. 01, no. 02, pp. 91-98, 2017. 